\title{
KARAKTERISTIK ANAK BERKEBUTUHAN KHUSUS DI SEKOLAH DASAR NEGERI (INKLUSI) DI KOTA PALANGKA RAYA
}

\section{Children Characteristics of Special Needs in Primary School (Inclusion) in Palangka Raya}

\author{
*Agung Riadin, Misyanto, \& Dwi Sari Usop \\ Primary School Teacher Study Program, Universitas Muhammadiyah Palangkaraya, RTA Milono St. Km.1,5 \\ Palangka Raya, Indonesia \\ *e-mail : agung riadin@yahoo.com
}

\begin{abstract}
ABSTRAK
Orang tua anak-anak berkebutuhan khusus menginginkan anaknya untuk dapat bersekolah di sekolah umum, bersamasama dengan anak-anak lainnya. Keinginan tersebut didukung pemerintah dengan mencanangkan sekolah inklusi. Penelitian ini bertujuan : 1). Mengetahui karakteristik anak berkebutuhan khusus di Sekolah Dasar Negeri (Inklusi) di Kota Palangka Raya, 2). Mengetahui dampak hadirnya anak berkebutuhan khusus di Sekolah Dasar Negeri (Inklusi) di kota Palangka Raya, 3). Mengetahui kemampuan yang dimiliki anak-anak berkebutuhan khusus di Sekolah Dasar Negeri (Inklusi) di kota Palangka Raya. Adapun pendekatan penelitian ini yang digunakan adalah pendekatan kualitatif. Metode pengumpulan data menggunakan wawancara, observasi, dan dokumentasi. Hasil penelitian ini menyatakan bahwa karakteristik anak-anak berkebutuhan khusus secara individual berbeda-beda. Namun, karakteristik utamanya, yakni mengalami kelemahan di dalam bidang akademik. Disisi lain, anak-anak berkebutuhan khusus di Sekolah Dasar Negeri Inklusi Kota Palangka Raya lebih memiliki kelebihan pada bidang non akademik.
\end{abstract}

Kata kunci: Anak Berkebutuhan Khusus, Sekolah Dasar Negeri Inklusi, Karakteristik Anak

\begin{abstract}
Parents of children with special needs want their children to attend public schools, together with other children. The desire is supported by the government by launching an inclusive school. This study aims: 1). Knowing the characteristics of children with special needs in Elementary School (Inclusion) in Palangkaraya City, 2). Knowing the impact of the presence of children with special needs in Elementary School (Inclusion) in Palangka Raya city, 3). Knowing the abilities of children with special needs in Elementary School (Inclusion) in Palangka Raya city. The research approach used is qualitative approach. Methods of data collection using interviews, observation, and documentation. The results of this study indicate that the characteristics of children with special needs individually vary. However, its main characteristics, namely experiencing weakness in the academic field. On the other hand, children with special needs in Palangka Raya City Inclusion School have more advantages in the non academic field.
\end{abstract}

Keywords: Children with Special Needs, Inclusive State Elementary School, Characteristics of Children

\section{PENDAHULUAN}

Setiap orang tua menginginkan dikaruniai anakanak yang lahir dalam kondisi normal, memiliki kondisi fisik dan mental yang utuh. Faktanya, sebagian orang tua diberikan anak-anak berkebutuhan khusus. Utina (2014), mengemukakan definisi anak berkebutuhan khusus, yaitu anak yang mengalami gangguan fisik, mental, inteligensi, dan emosi sehingga membutuhkan pembelajaran secara khusus. Hal senada dikemukakan oleh Heward dan Orlansky (dalam Handayani, 2013), bahwa anak berkebutuhan khusus sebagai anak yang dalam proses pertumbuhan atau perkembangannya mengalami kelainan atau penyimpangan (fisik, mental, intelektual, social, emosional) sehingga memerlukan pelayanan pendidikan khusus.

Berbeda dengan Directgov (dalam Thompson, 2012), mengemukakan bahwa istilah anak 
berkebutuhan khusus ( $A B K)$ merujuk pada anak yang memiliki kesulitan atau ketidakmampuan belajar yang membuatnya lebih sulit belajar atau mengakses pendidikan dibandingkan kebnayakan anak seusianya. Senada dengan DIES (dalam Thompson, 2012), menyatakan bahwa anak-anak dikatakan berkebutuhan khusus jika mereka memiliki kesulitan belajar sehingga menuntut dibuatnya ketentuan pendidikan khusus bagi mereka.

Adapun pendidikan anak berkebutuhan khusus mendapatkan pendidikan khusus yang bernaung pada siistem pendidikan inklusif. Di dalam pendidikan khusus, anak-anak berkebutuhan tingkat ringan, sedang, maupun berat ditempatkan pada kelas regular (Karya, 2016). Di dalam pendidikan inklusif, pendidikan bagi anak berkebutuhan khusus dikelompokkan menjadi dua jenis, yaitu : pendidikan khusus dan pendidikan layanan khusus. Undang-undang No. 20 Tahun 2003 tentang Sistem Pendidikan Nasional mendefinisikan pendidikan khusus sebagai pendidikan bagi peserta didik yang memiliki tingkat kesulitan dalam mengikuti proses pembelajaran karena kelainan fisik, emosional, mental, sosial, dan atau memiliki potensi kecerdasan dan bakat istimewa (Kustawan \& Meimulyani, 2013).

Di Kota Palangka Raya, para orang tua dari anakanak berkebutuhan khusus yang berusia sekolah memanfaatkan kesempatan bersekolah di sekolah dasar negeri inklusi yang sejatinya merupakan sekolah umum. Suatu dilema yang dihadapi oleh para guru di Sekolah Dasar Negeri Inklusi yakni di dalam menghadapi anak-anak berkebutuhan khusus. Hal ini disebabkan pengetahuan guru yang masih sangat kurang mengenai anak-anak berkebutuhan khusus. Walaupun ada guru-guru yang telah mendapatkan pelatihan. Kondisi tersebut dapat disebabkan oleh banyaknya jumlah anak yang harus ditangani oleh guru, sedangkan satu kelas hanya dipegang oleh satu orang guru. Selain itu, faktor ekonomi dan tingkat pendidikan orang tua turut mempengaruhi kesulitan guru. Kesulitan yang dimaksud berhubungan dengan koordinasi perilaku anak selama di sekolah.

Mengacu pada permasalahan tersebut, menimbulkan pertanyaan: 1). Bagaimana karakteristik anak berkebutuhan khusus di Sekolah Dasar Negeri (Inklusi) di kota Palangka Raya?, 2). Bagaimana dampak hadirnya anak berkebutuhan khusus di Sekolah Dasar Negeri (Inklusi) di kota Palangka Raya?, 3). Bagaimana kemampuan yang dimiliki anak-anak berkebutuhan khusus di Sekolah Dasar Negeri (Inklusi) di kota Palangka Raya?

\section{METODOLOGI}

Pendekatan penelitian yang digunakan di dalam penelitian yang akan dilakukan ini adalah pendekatan kualitatif. Melalui pendekatan ini, peneliti akan dapat menggambarkan secara detail mengenai karakteristik anak berkebutuhan khusus di sekolah dasar negeri yang ada di kota Palangka Raya. Adapun metode pengumpulan data menggunakan observasi, wawancara, dan dokumentasi. Teknik analisis data menggunakan analisis deskriptif yang dapat menggambarkan secara detail mengenai karakteristik anak berkebutuhan khusus di sekolah dasar negeri inklusi 


\section{HASIL DAN PEMBAHASAN}

Penelitian dilakukan di 3 (tiga) Sekolah Dasar Negeri Inklusi, yakni : 1). SDN 3 Langkai, 2). SDN 11 Langkai, 3). SDN 12 Langkai. Ketiga sekolah ini menjadi sampel penelitian disebabkan ketiganya telah ditunjuk pemerintah sebagai sekolah inklusif sejak beberapa tahun lalu. Berikut jenis-jenis anak berkebutuhan khusus pada tiga sekolah inklusif tersebut.

Tabel 1. Daftar Nama Peserta Didik Berkebutuhan Khusus SDN 3 Langkai Palangka Raya

\begin{tabular}{|c|c|c|c|c|}
\hline $\mathrm{NO}$ & $\begin{array}{l}\text { NAMA } \\
\text { INISIAL }\end{array}$ & $\begin{array}{c}\text { JENIS } \\
\text { KELAMIN }\end{array}$ & KELAS & $\begin{array}{c}\text { JENIS } \\
\text { KELAINAN }\end{array}$ \\
\hline 1 & I.A. & Laki-laki & I & Hiperaktif \\
\hline 2 & M.M.S. & Laki-laki & I & $\begin{array}{l}\text { Kesulitan } \\
\text { Belajar }\end{array}$ \\
\hline 3 & F.A.B. & Laki-laki & III & Tuna Laras \\
\hline 4 & F.V.F. & Perempuan & III & $\begin{array}{c}\text { Kesulitan } \\
\text { Belajar }\end{array}$ \\
\hline 5 & M.R. & Laki-laki & III & Hiperaktif \\
\hline 6 & N.S. & Perempuan & III & $\begin{array}{c}\text { Kesulitan } \\
\text { Belajar }\end{array}$ \\
\hline 7 & J.U.P. & Perempuan & III & $\begin{array}{c}\text { Down } \\
\text { Syndrom }\end{array}$ \\
\hline 8 & M.R.A. & Laki-laki & III & $\begin{array}{l}\text { Kesulitan } \\
\text { Belajar }\end{array}$ \\
\hline 9 & $\mathrm{R}$ & Laki-laki & III & $\begin{array}{c}\text { Kesulitan } \\
\text { Belajar }\end{array}$ \\
\hline 10 & I.S. & Laki-laki & IV & $\begin{array}{c}\text { Kesulitan } \\
\text { Belajar }\end{array}$ \\
\hline 11 & A.R. & Laki-laki & IV & $\begin{array}{c}\text { Tuna } \\
\text { Wicara }\end{array}$ \\
\hline 12 & R.N.F. & Laki-laki & IV & $\begin{array}{c}\text { Tuna } \\
\text { Wicara }\end{array}$ \\
\hline 13 & A.H.M. & Laki-laki & $\mathrm{V}$ & $\begin{array}{c}\text { Tuna } \\
\text { Wicara, } \\
\text { Hiperaktif, } \\
\text { Kesulitan } \\
\text { Belajar }\end{array}$ \\
\hline 14 & Y.P.A. & Laki-laki & $\mathrm{V}$ & Tuna Netra \\
\hline 15 & B.B.S.R & Laki-laki & VI & $\begin{array}{c}\text { Tuna } \\
\text { Netra }\end{array}$ \\
\hline 16 & D.S.P. & Laki-laki & VI & $\begin{array}{c}\text { Kesulitan } \\
\text { Belajar }\end{array}$ \\
\hline 17 & I.K. & Laki-laki & $\mathrm{VI}$ & $\begin{array}{l}\text { Kesulitan } \\
\text { Belajar }\end{array}$ \\
\hline 18 & M.Q.A.R.S & Laki-laki & $\mathrm{VI}$ & $\begin{array}{c}\text { Hiperaktif, } \\
\text { Kesulitan } \\
\text { Belajar }\end{array}$ \\
\hline 19 & V.S. & Laki-laki & VI & $\begin{array}{c}\text { Hiperaktif, } \\
\text { Kesulitan } \\
\text { Belajar }\end{array}$ \\
\hline
\end{tabular}

Tabel 2. Daftar Nama Peserta Didik Kebutuhan Khusus SDN 11 Langkai

\begin{tabular}{|c|c|c|c|c|}
\hline NO & $\begin{array}{l}\text { NAMA } \\
\text { INSIAL }\end{array}$ & $\begin{array}{l}\text { JENIS } \\
\text { KELAMIN }\end{array}$ & KELAS & $\begin{array}{c}\text { JENIS } \\
\text { KELAINAN }\end{array}$ \\
\hline 1 & A.B.S.G. & Laki-laki & $\mathrm{I}$ & Hiperaktif, Autis \\
\hline 2 & C.N.R. & Laki-laki & I & $\begin{array}{l}\text { Autis, Delayed } \\
\text { Speech }\end{array}$ \\
\hline 3 & C.G.P & Laki-laki & $\mathrm{I}$ & $\begin{array}{c}\text { Autis, Delayed } \\
\text { Speech }\end{array}$ \\
\hline 4 & F.I.P.F. & Laki-laki & $\mathrm{I}$ & $\begin{array}{c}\text { Autis, Delayed } \\
\text { Speech }\end{array}$ \\
\hline 5 & N.E.W & Perempuan & 1 & $\begin{array}{l}\text { Delayed } \\
\text { Speech }\end{array}$ \\
\hline 6 & A.F.N. & Perempuan & II & $\begin{array}{c}\text { Kesulitan } \\
\text { Belajar }\end{array}$ \\
\hline 7 & A.A.M. & Perempuan & II & Tuna Rungu \\
\hline 8 & M.I.L. & Laki-laki & III & Hiperaktif \\
\hline 9 & F.J. & Laki-laki & III & Hiperaktif \\
\hline 10 & R.F.K.A. & Laki-laki & III & $\begin{array}{c}\text { Hiperaktif, } \\
\text { Delayed } \\
\text { Speech }\end{array}$ \\
\hline 11 & N.A. & Perempuan & IV & Autis Ringan \\
\hline 12 & A.J.A. & Laki-laki & IV & $\begin{array}{l}\text { Autis dan } \\
\text { Delayed } \\
\text { Speech }\end{array}$ \\
\hline 13 & N.C. & Perempuan & IV & $\begin{array}{c}\text { Delayed } \\
\text { Speech, } \\
\text { Kecenderungan } \\
\text { ADHD } \\
\end{array}$ \\
\hline 14 & K.SS.C. & Perempuan & $\mathrm{V}$ & Lamban Belajar \\
\hline 15 & A.A.B. & Laki-laki & $\mathrm{V}$ & Hiperaktif \\
\hline 16 & D.V.A. & Perempuan & V & $\begin{array}{c}\text { Lamban } \\
\text { Belajar, } \\
\text { gangguan } \\
\text { Pendengaran } \\
\end{array}$ \\
\hline 17 & F.D. & Laki-laki & $\mathrm{VI}$ & $\begin{array}{c}\text { Hiperaktif, } \\
\text { Lamban Belajar }\end{array}$ \\
\hline 18 & G.M. & Laki-laki & $\mathrm{VI}$ & Hiperaktif \\
\hline 19 & T.M. & Laki-laki & $\mathrm{VI}$ & Lamban Belajar \\
\hline 20 & $\mathrm{Y}$ & Laki-laki & $\mathrm{VI}$ & Lamban Belajar \\
\hline
\end{tabular}

Sementara itu, data SDN 12 Langkai Palangka Raya menunjukkan tidak ada variasi jenis kelainan dialami peserta didik. Jenis kelainan yang dialami lebih pada kesulitan belajar yang mengakibatkan mereka kesulitan di dalam memahami pelajaran di sekolah.

\section{Karakteristik Anak Berkebutuhan Khusus di Sekolah Dasar Negeri Inklusi di Kota Palangka Raya}

Sejalan dengan diri individu yang sejatinya memiliki perbedaan antara satu dengan lainnya, anak-anak yang bersekolah di SDN Inklusi di Kota Palangka Raya juga memiliki karakteristik yang 
berbeda-beda. Walaupun jenis kebutuhan khusus yang dimiliki ada yang sama. Secara umum, anakanak berkebutuhan khusus di SDN Inklusi Kota Palangka Raya sama-sama memiliki kesulitan di dalam proses penyerapan materi pelajaran yang diberikan guru. Kesulitan tersebut dapat disebabkan oleh kondisi kejiwaan anak-anak yang yang mendukung, seperti tidak tenang, tidak fokus, tidak mau diatur atau senang berbuat sesuka hatinya.

Sebagian anak yang tidak mau diatur, tidak mau memperhatikan guru dalam proses belajar. Ada yang memilih untuk menggambar daripada mendengarkan guru menjelaskan materi. Walaupun demikian, anak mampu menjelaskan gambar yang dibuatnya. Disisi lain, ada anak yang tidak dapat menuliskan jawaban dari soal-soal yang diberikan guru, tulisan yang tidak rapi atau hampir tidak dapat dibaca, maupun tidak dapat membaca walaupun sudah berada di kelas tinggi. Selain itu, terkadang anak-anak ini juga dapat mengganggu teman-temannya. Misalnya, mengambil barang milik teman atau menusuknusuk tubuh teman menggunakan pensil dan pulpen.

Kondisi-kondisi tersebut pada dasarnya disebabkan oleh kebutuhan khusus yang dialami. Selain itu, faktor ekonomi maupun tingkat pendidikan orang tua memiliki peran terhadap perilaku-perilaku anak. Sebagian orang tua memiliki tingkat ekonomi menengah ke bawah dan juga bekerja. Artinya, sebagian kedua orang tua sama-sama bekerja. Hal ini mengakibatkan anak kurang mendapatkan perhatian. Adapun sebagian orang tua tidak memahami dalam mendidik anak.

\section{Dampak Hadirnya Anak Berkebutuhan Khusus di Sekolah Dasar Negeri Inklusi di Kota Palangka Raya}

Dampak hadirnya anak berkebutuhan khusus di Sekolah Dasar Negeri di Kota Palangka Raya membawa pembaharuan bagi personil pendidikan. Personil pendidikan di sini adalah kepala sekolah, guru, serta tenaga kependidikan. Dalam rangka mendukung program pemerintah serta menaati peraturan perundang-undangan yang menyebutkan bahwa anak berkebutuhan khusus memiliki hak yang sama untuk mendapatkan pendidikan. Anak-anak berkebutuhan khusus juga harus bersekolah. Tidak hanya bersekolah di sekolah luar biasa, tetapi juga dapat bersekolah di sekolah umum.

Kondisi ini didukung oleh orang tua dari anak berkebutuhan khusus. Orang tua menginginkan anak-anak mereka dapat hidup normal sama dengan anak-anak lainnya. Mereka ingin anakanak mereka dianggap normal layaknya anakanak lainnya. Orang tua juga ingin anak-anak mampu bersosialisasi dengan teman-temannya. Sebagian orangtua mampu menerima bahwa anak mereka termasuk anak berkebutuhan khusus sebagian lagi tidak menerima. Hal ini yang mendasari orangtua anak berkebutuhan khusus menyekolahkan anak-anaknya disekolah umum.

Ditinjau dari pertemanan antara anak-anak berkebutuahn khusus dengan peserta didik lainnya tidak mengalami kesenjangan yang berarti. Hal ini disebabkan oleh guru sudah memberikan arahan kepada peserta didik lainnya untuk menerima dan membantu anak-anak berkebetuhan khusus dalam proses pembelajaran disekolah. Kondisi ini sangat menguntungankan sebab anak-anak berkebutuhan khusus belajar dari teman- 
temannya. Mereka mau mengikuti arahan temantemannya, meniru kegiatan yang dilakukan temantemannya. Tentunnya hal ini sangat membantu guru dalam membina anak berkebutuhan khusus terutama dalam segi bidang keterampilan dan kepribadian, walupun dari segi akademik sangat kurang.

\section{Kemampuan yang dimiliki Anak-anak Berkebutuhan Khusus di Sekolah Dasar Negeri Inklusi Kota Palangka Raya}

Tiga aspek penting yang ada di dalam diri individu dan mempengaruhi di dalam kehidupannya, yaitu aspek kognitif, afektif, dan psikomotorik. Dalam bidang pendidikan, ketiga aspek ini terwujud di dalam bidang akademik, kepribadian serta keterampilan. Tiga aspek ini juga yang menjadi sisi penilaian peserta didik di sekolah, merupakan bagian penentu kesuksesan bagi seorang peserta didik.

Ditinjau dari bidang akademik, peserta didik berkebutuhan khusus di sekolah dasar inklusi mengalami kesulitan di dalam mengikuti pelajaran. Kesulitan tersebut tampak di dalam kemampuan mereka memahami penjelasan guru serta mengerjakan tugas-tugas. Untuk memudahkan proses pembelajaran, guru dapat mengatur tempat duduk peserta didik berkebutuhan khusus pada barisan depan bersama teman-teman atau barisan depan pada posisi yang terpisah dari barisan teman-teman. Kondisi ini berbeda-beda di setiap kelas dan setiap sekolah. Penempatan peserta didik pada barisan depan terpisah dari temantemannya bertujuan agar guru dapat lebih leluasa mengendalikannya serta peserta didik lain bisa lebih fokus belajar. Adapun penempatan tempat duduk pada barisan depan juga diberlakukan bagi peserta didik tuna netra. Sedangkan bagi peserta didik berkebutuhan khusus lainnya tidak ditentukan.

Kesulitan belajar yang dialami menyebabkan peserta didik mengalami kebingungan menjawab tugas. Dalam hal ini mereka tidak mampu menjawab pertanyaan-pertanyaan yang diberikan, menyebabkan peserta didik tersebut tidak menuliskan jawabannya pada buku latihan sama sekali. Sedangkan peserta didik lainnya tidak mampu membaca walaupun sudah berada di kelas 6 (enam). Saat proses pembelajaran secara berkelompok, peserta didik berkebutuhan disatukan bersama dengan teman-teman lainnya. Ditinjau dari segi afektif, di mana perwujudannya adalah kepribadian peserta didik. Peserta didik memiliki kepribadian yang cukup baik. Secara umum, peserta didik mampu mengikuti serta menaati peraturan yang ditentukan oleh sekolah. Misalnya datang ke sekolah tepat waktu, mampu meletakkan sepatu pada rak sepatu yang telah diletakkan di depan ruang kelas masing, mampu melaksanakan piket kelas secara berkala. Ditinjau dari segi psikomotorik, di mana perwujudannya adalah ketrampilan. Peserta didik mampu melaksanakan piket kelas, dapat membantu bila guru meminta tolong.

Selain itu ada anak berkebutuhan khusus yang senang bermain musik. Sebagian anak juga rajin menjalankan ibadah contohnya adalah $\mathrm{F}$ peserta didik kelas III SDN 11 Langkai. Dalam bidang akademik $\mathrm{F}$ mengalami hambatan dalam belajar. Namun ketika pada saat bulan Ramadhan menjadi peserta didik yang rajin menjalankan ibadah puasa dengan maksimal dibandingkan teman-teman lainnya. Bahkan $\mathrm{F}$ juga tidak mau berbuka saat waktu berbuka puasa telah tiba. 


\section{KESIMPULAN}

Pola pengajaran anak berkebutuhan khusus di samakan dengan peserta didik lainya. Tidak ada peserta didik anak berkebutuhan khusus yang berprestasi. Nilai ditingkatkan sehingga memenuhi KKM sebab mengikuti peraturan setiap peserta didik harus naik kelas. Dalam pengerjaan tugas untuk Anak berkebutuhan khusus, diberikan jumlah soal yang lebih sedikit daripada temantemannya. Teman-teman mendukung dan membantu anak berkebutuhan khusus, tidak ada yang mengucilkan anak berkebutuhan khusus. Memiliki prestasi yang biasa-biasa saja, artinya tidak mengikuti perlombaan-perlombaan. Dari sisi akademik mengalami kesulitan dalam memahami proses pembelajaran. Dari segi kepribadian memiliki kemampuan untuk mentaati peraturan

\section{DAFTAR PUSTAKA}

Handayani, I.M. 2013. Interaksi social anak berkebutuhan khusus di SDN 016/016 inklusif Samarinda : Studi kasus anak penyandang autisme. eJournal SosiatriSosiologi. Vol. 1, No. 1. Pp. 1-9.

Karya, B. 2016. Implementasi kebijakan pendidikan inklusif pada SDN 9 Palangka di kota palangka Raya. Tesis. Universitas Muhammadiyah Palangkaraya. Tidak dipublikasikan.

Kustawan, D., \& Meimulyani, Y. 2013. Mengenal pendidikan khusus \& pendidikan layanan khusus serta implementasinya. Jakarta : Luxima

Thompson, J. 2012. Memahami anak berkebutuhan khusus. Jakarta : Erlangga

Undang - Undang No. 20 Tahun 2003 tentang Sistem Pendidikan Nasional.

Utina, S.S. 2014. Pendidikan anak berkebutuhan khusus. TADBIR : Jurnal Manajemen Pendidikan Islam, Vol. 1, No. 2, Pp. 72-78. 